\title{
THE ROLE OF RELIGIOUSITY AN INCREASE MANIFEST NEEDS AND PRODUCTIVITY OF HUMAN RESOURCES
}

\author{
Arizqi $^{1}$
}

\begin{abstract}
* Affiliation:
${ }^{1}$ Dept. of Economics, Sultan Agung Islamic University (UNISSULA), Jl. Raya Kaligawe Km. 4 PO Box. 1054, Semarang 50112, Indonesia, Telp: 024-6583584, Fax: 024-6582455

Email:

arizqi@unissula.ac.id
\end{abstract}

\begin{abstract}
:
This study aimed to examine the effect of religiosity on the manifest needs which consists of need for achievement, need for power, need for affiliation. In addition, this study also aims to examine how the manifest needs role in triggering an increase in labor productivity of Human Resources.

The research was conducted by testing SEM (Structural Equation Modeling) with the help of statistical software SmartPLS. The study was conducted using a survey by distributing questionnaires to 79 lecturers remain functional positions (JAFA) Sultan Agung Islamic University. In determining the amount of the sample number of researchers using the formula slovin with proportional random sampling technique.

The results showed that religiosity have significant influence on the improvement of manifest needs, and then to increase productivity of human resources can be improved through increasing of manifest need in dimension need for achievement, while the need for power and the need for affiliation are not able to explain the productivity of the organization.

Keywords: religiosity, manifest needs, productivity, SmartPLS.
\end{abstract}

\section{INTRODUCTION}

Religiosity is generally described related to cognition (knowledge of religion, religious beliefs) that affect what is done with the emotional attachment or emotional feelings about religion, and or behavior, such as attendance at a place of worship, reading scripture, and pray (Crownal et al; Elci, 2007). Someone who says they are religious are trying to understand life and life more deeply than the mere outward boundary, which moves in the vertical dimension of life and transcends this life (Shafiq and Wahyuningsih, 2009).

To achieve of organizational goals, human resources need motivation to work more diligently. Seeing the importance of human resources within the organization, it would require more serious attention to the task at hand so as to achieve organizational goals. 
McClelland in theory that is Manifest Needs. Manifest Needs is a necessity arising from within the Human Resources consisting of Need for achievement, Need for power, and the Need for Affiliation. Every organization has always tried to keep its human resources can be accomplished in the form of providing maximum work productivity. Productivity of human resources for a company is important as a measure of success in running the business. Due to the higher productivity of human resources within the company, the company's profits and productivity will increase.

Many studies have investigated the motivation of human resources, but not much to examine the motivation of dimensions McClelland is manifest needs, with dimensions of need for achievement, need for power, especially need for affiliation that receives the least attention from researchers. Then many of the previous studies that discuss the relationship between motivation on performance, job satisfaction, etc. Not a lot of research that examines the relationship dimension theory McClelland motivation to work productivity. Therefore, this study intends to analyze in more integrative about religiosity and manifest relationship needs to work productivity of human resources, as well as examine how the relationship between the manifest needs to be moderated by the variable productivity after professional commitment.

\section{LITERATURE REVIEW \\ Religiosity}

According to Elci (2007), described the general religiosity associated with cognition (knowledge of religion, religious beliefs) that affect what is done with the emotional attachment or emotional feelings about religion and behavior, such as the presence of place of worship, reading scripture, and pray. Fetzer (2003) in "Multidimensional measurement of religiousness or spirituality for use in health research", explains the signs (indicators) religiosity consists of: the importance of religious values in daily activities (daily spiritual importing), the practice of religion (religious practice), religion as coping (religious coping), and organizations or religious activities (organizational religiousness). Then sign (indicator) of Fetzer is also to be used as indicators in this study.

The application of religious values in the Unissula own one of them with the implementation of Islamic Academic Culture (Budai). Academic culture Islami (Budai) itself began to be applied in Unissula since August 18, 2005 until now. Unissula commitment to the vision of Bismillah Building a Generation Khaira Ummah have consequences on the optimization of the role to be part of the movement to build the Islamic civilization. In this context, the strategy of Islamic Academic Culture (Budai) an option to start a movement with the reconstruction program and behavioral sciences on the basis of Islamic values. Based Unissula Rector's Decree No. 4654 / B.1 / SA / VIII / 2007, Academic Culture Islami (Budai) in Unissula include: movement of Islamic dress, movement thaharah (environmentally clean, healthy, and safe), and the movement of prayer in congregation, adab association sons and daughters, adab receiving guests, and manners inside and outside the classroom. 


\section{Manifest Needs}

Manifest Needs is a necessity arising from within the Human Resources consisting of Need for achievement, need for power, and need for affiliation.

Need for achievement can be interpreted as a requirement in a person to do a particular task or activity or task as well as possible in order to achieve the laudable predicate (Mangkunagara, 2006), in the presence of self-achievement motivation in human resources will foster a spirit of healthy competition, will foster human resources responsible, as well as a human resource becomes a creative person. According Steers, Richard M. and D. Braunstein (1976) stated that indicators of need for achievement is characterized by seriousness in improving the performance, enjoy the difficult challenges, the progress made in completing the task, set goals, enjoy the satisfaction of a settlement difficult task.

Need for power is based on the needs of one's desire to organize and lead others. Power is the probability that makes a person within a social relationship are in a position to carry out his own desires and get rid of all obstacles that crossed in front of him. The signs (indicators) those who pursue power needs by Steers, Richard M. and D. Braunstein (1976) is enjoying the competition and victory, enjoy responsibility, direct complaint, the ability to influence others, control the events around.

Need for affiliation is a requirement based on the desire to obtain or run a good relationship with others. People who have a high need for affiliation usually have the pleasure of affection and tend to avoid disappointment because it was rejected by a social group. Individually they tend to try to foster a pleasant social relationships, a sense of intimacy and understanding. Sign (indicator) those who pursue social need for affiliation or by Steers, Richard M. and D. Braunstein (1976) is sharing problems outside of work, want to be liked, to build a close relationship with the group, to enjoy being part of the group, not the individual work.

H1: There is a significant relationship between religiosity of the needs for achievement.

H2: There is a significant relationship between religiosity of the need for power.

H3: There is a significant relationship between religiosity of the needs for affiliation.

\section{Productivity}

Productivity is the ability to produce something of duties and employment provided by the organization/company. Performance of HR management success in college is to develop the potential of Lecturer, meant to empower the human resources component of the college through the optimal action against the factors forming personal labor productivity Lecturer, Lecturer and functional groups. The principal tasks of lecturers consists of three major tasks Tri Dharma College, in GR No. 60 In 1999, Tri Dharma College include education, research, and community service. Three main elements above the Tri Dharma College Lecturer used as indicators of labor productivity.

Mcclelland (1961, robbin was quoted by, 2003\& mangkunegara amp, 2006), in theory been the motivation that productivity develop human resources very determined by conditions of the soul that drives someone to able to achieve a feat he wants.

Frederick study (2010) showed that significantly students United States has the highest level of productivity oriented motivation than students from East Asia and other western 
students. Research conducted by Nenet Natasudian Jaya in 2013, research shows that the three dimensions of motivation variable need for achievement (need for achievement), need for power (demand for power), and the need for affiliation (need for affiliation) have a significant influence on work productivity.

H4: There is a significant relationship between need for achievement on productivity.

H5: There is a significant relationship between need for power on productivity.

H6: There is a significant relationship between need for affiliation to productivity.

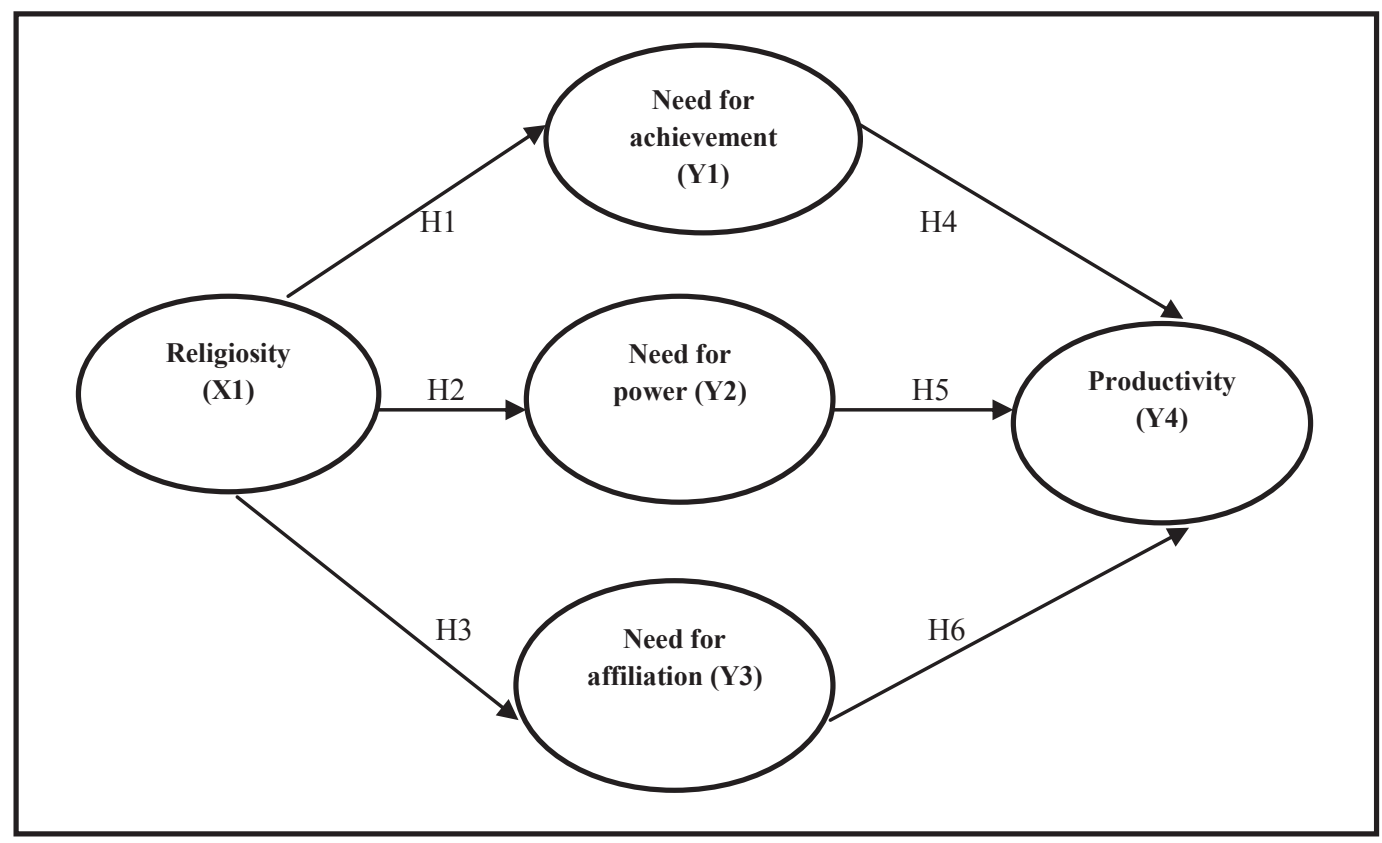

Figure 1. Research Empirical Model

From Figure 1 it appears that religiosity influences that manifest need for achievement needs (need for achievement), need for power (demand for power), and the need for affiliation (need for affiliation), then manifest needs affects productivity. Variable religiosity is free or independent variable, then the dependent variable or dependent variable is the manifest needs that need for achievement (need for achievement), need for power (the need for power), and the need for affiliation (need for affiliation).

\section{METHOD}

This type of research is an explanatory research (Explanatory Research) is trying to find out the relationship between the study variables. The nature of this research is a causal relationship between the variables through hypothesis testing. Source of research data derived from the respondents and literature / books / journal. Types of research data is a primary and secondary data. Data collection was done in this study using a questionnaire. The population in this study is a permanent lecturer functional positions (Jafa), namely, Assistant Expert, Associate Professor, Associate Professor and Professor of the criteria for tenure of more than 2 years. The research was conducted using survey by distributing questionnaires to 79 lecturers remain functional positions (Jafa). In determining the amount of the sample the researchers used a formula slovin with proportional random sampling technique. 


\section{RESULTS AND DISCUSSION}

The number of questionnaires in the spread as much as 79 questionnaires, which did not return the questionnaire to as many as 13 in the questionnaire if the number of 66 questionnaires or $83.54 \%$.

\section{Outer Model Results}

Based on the test convergent validity, it is known that the Convergent Validity of indicators of religiosity, need for achievement, need for power, need for affiliation, and productivity have outer loading values $>0.5$ thus all the indicator variable is valid.

Table 1. Convergent validity Variable Research

\begin{tabular}{lllll}
\hline Information & $\begin{array}{l}\text { original sample } \\
\text { estimate }\end{array}$ & $\begin{array}{l}\text { mean of } \\
\text { subsamples }\end{array}$ & $\begin{array}{l}\text { Standard } \\
\text { deviation }\end{array}$ & T-Statistic \\
\hline Religiosity & & & & \\
X1.1 & 0.703 & 0.667 & 0.134 & 5.235 \\
X1.2 & 0.713 & 0.675 & 0.137 & 5.219 \\
X1.3 & 0.696 & 0.707 & 0.074 & 9.363 \\
X1.4 & 0.825 & 0.831 & 0.047 & 17.631 \\
\hline N-Ach & & & & \\
Y1.1 & 0.824 & 0.828 & 0.034 & 24.178 \\
Y1.2 & 0.560 & 0.539 & 0.138 & 4.057 \\
Y1.3 & 0.516 & 0.518 & 0.129 & 3.986 \\
Y1.4 & 0.795 & 0.785 & 0.092 & 8.634 \\
Y1.5 & 0.715 & 0.699 & 0.109 & 6.548 \\
\hline N-Pow & & & & \\
Y2.1 & 0.706 & 0.707 & 0.094 & 7.490 \\
Y2.2 & 0.761 & 0.744 & 0.084 & 9.071 \\
Y2.3 & 0.720 & 0.708 & 0.106 & 6.823 \\
Y2.4 & 0.707 & 0.710 & 0.072 & 9.874 \\
Y2.5 & 0.615 & 0.582 & 0.158 & 3.890 \\
\hline N-Aff & & & & \\
Y3.1 & 0.660 & 0.626 & 0.148 & 4.464 \\
Y3.2 & 0.792 & 0.788 & 0.065 & 12.264 \\
Y3.3 & 0.530 & 0.523 & 0.157 & 3.367 \\
Y3.4 & 0.759 & 0.767 & 0.066 & 11.579 \\
Y3.5 & 0.596 & 0.577 & 0.181 & 3.303 \\
\hline Productivity & & & & \\
Y4.1 & 0.764 & 0.765 & 0.087 & 8.820 \\
Y4.2 & 0.881 & 0.659 & 0.141 & 4.553 \\
Y4.3 & 0.811 & & & \\
Y4.4 & 0.642 & & 0.055 & 15.979 \\
\hline & & & & 7.805 \\
\hline
\end{tabular}


From the output SmartPLS above all construct composite reliability values above 0.7 . So it can be concluded that all the variables are reliable. The following table of values of composite reliability :

Table 2. Composite Reliability

\begin{tabular}{lc}
\hline & Composite Reliability \\
\hline Religiosity & 0.825 \\
N-Ach & 0.817 \\
N-Pow & 0.830 \\
N-Aff & 0.803 \\
Productivity & 0.859 \\
\hline
\end{tabular}

\section{Inner Model Results}

Inner assess the model is looking at the relationship between latent constructs to see the results of parameter estimation path coefficients and the level of significance (Ghozali, 2008). Base used in testing the hypothesis is contained in the output value result for the inner weight as shown in Table 3 below:

Table 3. Result for inner weight

\begin{tabular}{lcccc}
\hline & $\begin{array}{c}\text { original sample } \\
\text { estimate }\end{array}$ & $\begin{array}{c}\text { mean of } \\
\text { subsamples }\end{array}$ & $\begin{array}{c}\text { Standard } \\
\text { deviation }\end{array}$ & T-Statistic \\
\hline Religiosity -> N-Ach & 0.997 & 0.997 & 0.094 & 10.619 \\
Religiosity -> N-Pow & 0.578 & 0.592 & 0.136 & 4.240 \\
Religiosity -> N-Aff & 0.631 & 0.662 & 0.134 & 4.701 \\
N-Ach -> Productivity & 0.101 & 0.078 & 0.253 & 0.399 \\
N-Pow -> Productivity & 0.211 & 0.230 & 0.184 & 1.149 \\
N-Aff -> Productivity & 0.199 & 0.239 & 0.228 & 0.869
\end{tabular}

Hypothesis 1 which states religiosity significant effect on the need for achievement (need for achievement) is received. This is evidenced by the coefficient of 0.997 and a significant parameter t-statistic $10619>$ t-table 1.96. Hypothesis 2 which states religiosity significant effect on the need for power (demand for power) is received. This is evidenced by the coefficient of 0.578 and a significant parameter t-statistics 4240> t-table 1.96. Hypothesis 3 which states religiosity significant effect on the need for affiliation (need for affiliation) is received. This is evidenced by the coefficient of 0.631 and a significant parameter t-statistics $4701>$ t-table 1.96 .

Hypothesis 4 indicates the need for achtievement (need for achievement) a significant effect on productivity rejected. This is evidenced by the value of parameter 0101 and significant coefficient t-statistic $0.399<\mathrm{t}$-table 1.96. Hypothesis 5 stated need for power (demand for power) significantly affects productivity rejected. This is evidenced by the coefficient of 0.211 and a significant parameter t-statistic $1.149<\mathrm{t}$-table 1.96. Hypothesis 6 stating Need for affiliation 
(need for affiliation) a significant effect on productivity rejected. This is evidenced by the value of the parameter coefficients of 0.199 and significant t-statistic $0.869<\mathrm{t}$-table 1.96 .

\section{Discussion}

Religiosity significant effect on the manifest needs which consists of need for achievement (need for achievement), need for power (the need for power) and the need for affiliation (need for affiliation). The religious foundations of the religion of Islam is taken from the Quran and Al-Hadith which is the fundamental guide and instructions for Muslims in performing their religious teachings and in carrying out daily activities. A lecturer, when the work was always apply religious values then it will work with the intention of worship, earnestly improve motivation in itself is motivation to meet the needs of accomplishment. That is, the higher the religiosity, the higher the motivation to meet the needs of achievement. Conversely, the lower religiosity the lower the level of motivation to meet the needs of achievement. Value religiosity that exists within Lecturer push to carry out the mandate power with more sincere and just because of Allah. Religious activities are conducted regularly, including the campus Duha Assembly held every Friday morning with studies to Islamization, Islamic Spiritual Enhancement Programme (ISEP) is the evening prayer held in the third week of each month, Halaqah Ulama, seminar Islamic, and other programs to encourage and increase the motivation for affiliation between the members. Affiliate here in question is silaturrahmi among others. Gathering is basically the teachings of Islam which is highly recommended. As included here among the Qur'an on a fragment of paragraph 1 letter Nisa "And bertaqwalah to God that the (use) his name you ask each other to each other, and (guard) silaturrahim relationship.

Manifest needs consisting of Need for achievement (need for achievement), need for power (the need for power) and the need for affiliation (need for affiliation) had no effect on productivity. Increased need for achievement (need for achievement) within the human resources are not necessarily able to increase work productivity. This can be caused due to external factors (external) yourself a human resources. In this case the lack of support from the organization to be one of the factors that cause the need for achievement (need for achievement) has no effect on work productivity. The absence of a relationship between the need for power (the need for power) on the productivity of work in this case because the organization or scope of work where the respondent has implemented a policy to human resources, such as a promotion, a clear career path, as well as definite rules against human resources. So in this study, the presence or absence of need for power (demand for power) within the human resources will continue to require the respondent in implementing its work (Tri Dharma College). In addition, the lack of correlation between need for power (the need for power) on work productivity as well as the study site is educational institutions (Lecturer as respondents), where power is not the main goal. The main achievement is a lecturer at the Functional academic thus less interested in power (power). The absence of a relationship between the need for affiliation (need for affiliation) on the productivity of work in this case because of the academic institutions is determined by himself, is more on self-development. So sometimes override respondents affiliates, except in the affiliate there is knowledge sharing among respondents. Respondents consider that increasing labor productivity is not whether or not related to the affiliates they do. 


\section{CONCLUSION}

Manifest needs which consists of need for achievement (need for achievement), need for power (the need for power) and the need for affiliation (need for affiliation) is strongly influenced by the values of religiosity. A lecturer will be motivated in him to work better to get the need for achievement, run the trust authority with a more sincere and just because of Allah and seek to establish good relations with fellow servants of Allah.

\section{LIMITATIONS AND FUTURE RESEARCH AGENDA}

This study is limited to the scope of educational organizations, namely Lecturer as respondents which is based on self-development, so it needs Manifest consisting of need for achievement (need for achievement), need for power (the need for power) and the need for affiliation (need affiliated) less implemented.

Then agenda for future research include: 1) Need to put more relevant variables that can affect work productivity, as well as adding other variables more suitable to the educational organizations such as knowledge sharing. 2) Need to conduct research with a different type of organization that is better suited to the needs of manifest variables, such as the organization of manufacturing, services, and government.

\section{REFERENCES}

Ahyadi Abdul Azis. (2005). Psikologi Agama: Kepribadaian Muslim Pancasila. Cet. V; Bandung: Sinar Baru Algensindo.

Bhukuvhani, et, al. (2014). Effect of electronic information resources skills training for lecturers on pedagogical practices and research productivity. International Journal of Education and Development using Information and Communication Technology. Vol 8 (1). 16-28.

Departemen Agama RI. (2006). Al-Qur'an dan Terjemahnya. Jakarta: Pustaka Agung Harapan.

Elci, Meral. (2007). Effect of Manifest Nrrds, Religiousity and Selected Demografics On Hard Working: An Empirical Investigation in Turkey. Journal of International Business Research, Volume 6, Number 2.

Fetzer, J. E. (2003). Multidimensional measurement of religiousness atau spirituality for use in health Research : A report of the Fetzer Institute / National Institute on aging working group. Fetzer Institute.

Gellerman, S.W. (1984). Motivasi dan Produktivitas. (cetakan Pertama). Alih bahasa: Soepomo S. Wardoyo. Jakarta: Djaya Pirusa.

Imam, Ghozali. (2006). Aplikai Analisis Multivarite dengan SPSS, Cetakan Keempat, Badan Penerbit Universitas Diponegoro, Semarang.

Hani, T. Handoko. (2003). Manajemen. Cetakan Kedelapanbelas. J iiiii BPFE Yogyakarta, Yogyakarta. 
Herzberg F. (2000). Frederick Herzberg's Motivation and Hygiene Factors. http://businessballs. com/herzberg.htm [12 September 2009].

Hidayat, S. (2008). Hubungan minat terhadap profesi guru dan motivasi berprestasi dengan keterampilan mengajar. Jurnal pendidikan dan kebudayaan, 1140.

Jaya, N. Natasudian. (2013). Measuring productivity of the Kopertis Lecturers at the private higher education Institutions in Mataram. International Journal of Science and Engineering Investigations, vol.2, issue 21, October 2013. Mahasaraswati University of Mataram. Mangkunegara, A. P. (2006). Evaluasi kinerja SDM. Bandung: PT Refika Aditama.

Manulang. (2013). Pengantar Bisnis. Jakarta : PT. Indeks. Munandar, A. S. (2010). Psikologi industri dan organisasi. Tangerang: UI-Press.

Muzakkir. (2013). Hubungan religiusitas dengan perilaku prososial mahasiswa angkatan 2009/2010 fakultas tarbiyah dan keguruan UIN Alaudin Makassar. Jurnal Diskursus Islam, Volume 1, Nomor 3, Desember 2013.

Narimawati, S. E. U. (2007). The Influence of Work Satisfaction, Organizational Commitment and Turnover Intention Towards the Performance of Lecturers at West Java's Private Higher Education Institution. Journal of Applied Sciences Research, 3(7), 549 - 557.

Neuroth, M. (2009). The value of (electronic) content for research productivity. Elsevier.

Pemerintah Republik Indonesia, (1999), Peraturan Pemerintah Republik Indonesia Nomor 60 Tahun 1999 tentang Pendidikan Tinggi. Kementerian Negara Sekretaris Negara Republik Indonesia, Jakarta.

Suharti L., Fransiska R., dan Wattimuna, R.T. (2014). The Role of Work Ethos as Mediating Variable for The Influence of Organizational Culture and Religiosity on Employee's Loyalty. The 2nd IBEA - International Conference on Business, Economics and Accounting.

Undang-Undang Republik Indonesia Nomor 14 Tahun 2005 tentang Guru dan Dosen. (2005). Jakarta: Kementerian Pendidikan Nasional. 